\title{
CALVYN EN DIE GRENSE VAN DIE KERK
}

\author{
Prof. B. Spoelstra
}

\section{Calvyn formuleer teenoor Rome, Anabaptiste}

Die Reformasie wentel om die leer van die kerk. Kerkhervorming wil immers die kerk terugbring binne sy eintlike grense. Rome het die grense van die universele kerk en koninkryk van God laat saamval met die sigbare kerk. Die bekende ubi papa ibi ecclesia toon hoe die grense van die kerk met die institusionele priesterdom geïdentifiseer is.

Luther maak radikaal onderskeid tussen die aardse en hemelse ryke. Die eintlike ware kerk, die liggaam van Christus behoort tot die hemelse en word begrens deur die saligmakende geloof. Dit is dus onsigbaar en onkenbaar op aarde. Die sigbare institusionele organisasie behoort tot die aardse bedeling, kan territoriaal afgegrens word, is preekinstituut om die geloof te werk wat die liggaam van Christus bou.

Die Anabaptiste (in verskillende vorme en aksente) vereenselwig soos Rome die sigbare en onsigbare gedaantes van die kerk, maar so dat hulle volmaakte kerk en liggaam van Christus in hulle aardse kerkgemeenskap vind. Die doop op geloofsbelydenis trek die grens sodat die sigbare geloofsgemeenskap derhalwe ook die volstrek heilige kerk onder regering van Christus is. Daarom staan hulle radikaal vreemd aan en teenoor hierdie wêreld, veral teenoor alle gesag wat op staat of kerk rus.

Calvyn proklameer sy visie op die kerk en hoe die kerk begrens word binne en in dialoog met hierdie verwarrende leef- en dinkwêreld en teenoor Rome en Wederdopers. Calvyn het met bewonderingswaardige insig reeds in die eerste uitgawe van sy Institutie 1536 sy grondgedagte aangedui. In volgende uitgawes van die Institusie het hy nooit nodig gehad om daarop terug te kom nie, maar het hy dit in die lig van sy ervaring met Rome, Libertyne en Anabaptiste uitgebou. Met sy tweede koms na Genève het hy in sy Ordonnances Ecclesiastiques 1543 aan sekere gedagtes ordelike vorm gegee. Daarna het hy in sy Kommentare en verder in enkele traktate hom duidelik uitgespreek.

\section{Calvyn formuleer antiteties maar vanuit allesbeheersende ekumenisiteit}

Calvyn was oënskynlik die jong Bybelse humanis wat omstreeks 1532 betrokke geraak het by die stryd om geestelike vernuwing in die kerk met die gepaardgaande verwarring, chaos en spanning wat die begeerte om God ooreenkomstig sy Woord te dien in die staat meegebring het. Sy voorwoord by sy Institusie dui aan dat die Institusie in 1536 die grense van die kerk binne die corpus christianum, teenoor die ius patronatus in sacra trek.

Hieruit sou 'n mens kon aflei dat Calvyn rigoristies en antiteties die ware kerk teenoor Roomse institusionalisme, Anabaptistiese sepe- 
ratisme en spiritualisme en politieke erastianisme sou begrens. Calvyn benader die kerklike begrensing egter vanuit 'n allesbeheersende ekumenisiteit. Die ware kerk is die eenheid onder ware gelowiges. Hy ken net een kerk van Christus. Hy is pastoraal bewoë en byna irenies wanneer hy handel oor gebreke onder gelowiges wat die kerk is. Die institusionele variasies geniet hoogstens in die verbygaan sy aandag. Hy waarsku steeds dat gegewe verskille in seremonies, liturgie, kerkregering en selfs punte van die leer nie die kerk bepaal of mag bepaal nie. 'n Soeke na institusionele en organisatoriese eenheid, enersheid en eenvormigheid met die sulkes, soos ons kontemporêre gedagtegang oor kerkeenheid en ekumene meermale gaan, kom nie by Calvyn voor nie.

Op sterkte van die empiriese realiteit van die una sancta catholica in die ryk geskakeerde mensewêreld noem hy Wederdopers in sy Institusie „broeders" (hoewel hy die hardnekkiges uiteindelik met skerp woorde kan ekskommunikeer); het hy 'n oog vir die gelowige in die Roomse instituut, hoewel hy die pousdom genadeloos afwys omdat hulle die Woord nie gehoorsaam nie. Calvyn werk van 1535 tot 1542 dan ook veral en met merkwaardige sukses onder Rooms-Katolieke, Libertyne en Anabaptiste om die Una sancta in die eenheid van kerkgemeenskap t.o.v. die leer en lewe te bewerkstellig. Die vierde boek in die uitgawe van die Institusie in 1543 bevat gevolglik die mees uitgebreide leer oor die kerk.

\section{Vertrekpunt in die ordinatio Dei}

Calvyn gaan vir sy unieke ekklesiologie en politologie uit van die ordinatio Dei. God orden onderskeie geestelike en politieke instellings. God het 'n natuurlike orde met eie wette en owerhede (magistrate) vir burgerlike samelewing (regimen politicum) daargestel. Ons moet diegene eer wat oor ons gestel is. Dit stel hy teenoor Dopers en rewolusioniste. Vanweë die sonde wat tot almal deurgedring het, het God deur die regverdigmaking en vergewing van sondes egter ook 'n regimen spirituale met sy Woord en Wet daargestel (ordinatio Dei). Die Heilige Gees onderrig die mens in sy gewete deur hierdie verordening sodat hy God weer op die regte wyse kan vrees en dien. Die ,l'honneur et gloire de Dieu' word gevolglik deur die sanctitas et puritas vitae bereik.

Die Woord bevat die imperium, decorum en mandatum Dei. Daarom sal hierdie Woord as sinoniem vir die ordening van God en as objektiewe kenteken die grense van die kerk bepaal.

\section{Vertrekpunt in die pneuma}

Die Heilige Gees het ook 'n tweërlei taak: Hy beteuel diegene wat goddeloos lewe en $\mathrm{Hy}$ regeer in besonder in die hart van die gelowiges. Saam met die objektiewe ordinatio Dei in Wet en Woord speel die Heilige Gees deurgaans dialekties 'n bepalende rol. Hy tree in die gewone orde nooit sonder die Woord op nie. "It is the Word, the Son of God, then who is the fons et origo of revelation and of those ordinations...". Maar dit geskied so: "Where ever 
the ordinatio and spiritus Dei are correlated, there is order; where the Spirit works apart from the ordinatio Dei, there is the extraordinary". ${ }^{4}$ Die Heilige Gees werk die besondere geloof en gehoorsaamheid waardeur die kerk onder mense sigbaar word. Derhalwe lê die wortels van die kerk diep in die raad, ordinansies en voorsienigheid van God. Hy realiseer die kerk deur sy Woord en Gees wanneer en waar mense dinamies saam en na Christus toe kom, deur geloof en in geloof, 'n gemeenskap wat die kerk is.

Calvyn dink as teoloog vanuit God oor die kerk en nie vanuit die mens nie. Die grense van die kerk is dus deur God vasgestel en word bepaal deur sy Woord en Gees. So is die kerk wesenlik anders as enige gewone menslike samelewingsverband, instituut of struktuur.

\section{Die grens tussen kerk en staat}

Op sterkte van die ordinatio Dei noem Calvyn die Wederdopers se verwerping van die burgerlike orde en jurisdiksie van owerhede iudaica vanitas omdat hulle die ryk van christus deur die elemente van die natuurlike orde laat bepaal. Calvyn sê burgerlike regering sou nie nodig gewees het nie, indien almal volmaak was. Vanweë die sonde is die burgerlike owerhede nodig sodat humaniteit onder die mense en religie onder die christene kan groei. Die owerheid het derhalwe 'n besondere roeping om die regte religie te handhaaf. Op die breë taak van die owerheid gaan ons nie verder in nie. ${ }^{5}$

Die geestelike regering het 'n prioriteit bo die natuurlike. Owerhede (magistrate, persone) is ook sondaars wat die Koning van die konings moet gehoorsaam. Derhalwe gaan die prediking van die Woord ook tot die owerhede uit.

Die „Les ministres de Geneeve au Conseil de Geneve; Articles bailles par les prêcheurs" 1536 omlyn die kerklike orde, sakramentsbedieninge, geloofsbelydenis, kategese en die tugoefening volgens die Institusie. Die volk van Genève is kerk wanneer hulle gemeente rondom die nagmaal is. Die owerhede moet daartoe meewerk omdat die volk die reformasie met 'n eed aangeneem het. Balke bevraagteken tereg die opvatting dat die owerheid diegene wat nie tot geloof kom nie, moet verban."

Reeds in 1536 proklameer Calvyn die „waarheidsmomente” van die Wederdopers, die vryheid van die kerk in regimen spirituale teenoor die owerheid se ius patronatus in sacra. Hy verwerp die volkskerk van die corpus christianum, omdat hy nie lidwees van die volk nie, maar geloof in Jesus Christus (wat salig maak), voorwaarde maak om deel te hê aan die nagmaal. ${ }^{7}$ Kerk is die gemeenskap van ,heiliges". Daarom eis Paulus die selfbeproewing ten opsigte van die geloof voor die nagmaal en moet toetrede van onwaardige mense, al is dit owerheidspersone, geweier word. Met die norm van geloof trek Calvyn duidelik die grens tussen kerk en volk, kerk en staat, kerk en samelewing.

Die Anabaptiste het gesê die grens van die kerk loop saam met dié van hulle „heilige" gemeente wat geloof bely het en op grond daarvan gedoop is. Die Corpus Christianum het die grense van die kerk met die volk of burgerlike gemeenskap laat saamval. Calvyn 
het met die Woord in so ver dit geglo en nageleef word die kerk binne in die volk, staat en gemeenskap begrens.

\section{Die gesag van die Woord gaan oor owerhede}

Wanneer Calvyn die owerhede onder die tug van die prediking (en nie prediker nie) stel en onverskilliges selfs toegang tot die nagmaal deur die herders laat ontsê, lyk dit asof hy "kerk" oor „staat" laat regeer, (veral wanneer ons, volgens moderne smaak, ",herders" met ,kerk as instituut" vereenselwig). In praktyk kan maklik gebeur dat 'n prediker se opinie met gesag van die Woord geïdentifiseer word. Dit is egter nie wat Calvyn bedoel het nie. Calvyn wou almal - van watter rang of stand ook al - onder die heerskappy van die Woord bring. Hy onderskei tussen die Woord as skat en die prediker as erdekruik en dink slegs aan afhouding en ekskommunikasie wanneer die Woord en Wet van God waarneembaar en hardnekkig opsy geskuif word.

„Er is geen sprake van dat de staat dienaresse van de kerk wordt of de kerk onder de staat gesteld wordt. Het gaat om het ambt en de opdracht van de vere divini minister die in volstrekte vrijheid alleen in gehoorzaamheid aan Gods Woord, zijn roeping vervult en om het ambt en opdracht van de overheid als ,praecipuum membrum ecclesiae' de openbare verkondiging van het evangelie te bevorderen ...".8

Mens moet nie so gou dink in ons terme van „kerk” of „staat” nie. „De reformatoren zijn niet zozeer geïnteresseerd in de macht van het christendom. Het gaat hen allereerst om de autoriteit van Gods Woord. Het is niet zo dat de kerk aan de staat wordt prijsgegeven of dat de staat dienaresse van de kerk wordt. Het gaat om de opdracht van het ,verbi divini ministerium' dat zich in de vrijheid van het Woord tot allen en ieder, ook tot de overheid, richt. Het gaat om de opdracht van de overheid die zichzelf verstaat als gave van God... Het gaat om de gehoorzaamheid van het geloof die elke persoonlijke willekeur van regenten of van predikanten uitsluit ..."."

Calvyn trek die grens tussen kerk en owerheid so dat wesenlike momente van Luther, Augustinus (De Civitate Dei) en die Anabaptiste saamvloei. Calvyn korrigeer die twee ryke leer van Luther daarin dat hy nie volstaan om die Woord te preek nie, "maar gezocht moet worden naar wegen, waardoor het Woord Gods gestalte gaat krijgen in het leven en samenleven, en in de overheid als ,externum medium salutis' ".10

\section{Net een begrensde kerk}

Calvyn dink vir geen oomblik aan die moontlikheid dat daar twee of meer kerke kan wees nie. Daar is net een kerk wat die katolieke gemeenskap, die liggaam van Christus is. Christus is die Hoof van die liggaam, Herder van die een volk van God. Die kerk is die gemeenskap waarin al die uitverkorenes vergader is. Om dus in terme van twee of drie kerke te dink, sou Christus ,verskeur”. 
Calvyn sê: „Die uitverkorenes van God is altyd tesame in Christus geheg en verbonde dat hulle as 't ware aan een Hoof hang en vas is en ewe so asof hulle in een liggaam tesame groei, in hierdie eenheid aan mekaar kleef soos lede van een en dieselfde liggaam: waarlik een geword, soos deur een geloof, hoop en liefde en tegelyk deur een en dieselfde Gees van God, tesame leef, nie alleen met die oog op dieselfde erfenis van die ewige lewe nie, maar ook met die oog op die gemeenskap met God en Christus waartoe hulle geroep is".11 Hierdie kerk kan geskend en gebreek word, selfs deur diegene wat geroep is om dit te versorg, maar dan bly daar altyd oorblyfsels in die sigbare werklikheid oor soos God aan Elia getoon het.

\section{Net een kerk deur die verbond begrens}

Wanneer Calvyn self in die vierde boek van die Institusie, eerste hoofstuk, oor die kerk begin handel en dus die kerk moet defineer, begin hy met geloof wat die prediking gewek het. Agter die sigbare kerk is daar die onsigbare kerk wat begrens of bepaal word deur uitverkiesing en die inwendige roeping van God. Die goddelike verbond skei 'n besondere volk, 'n kerk, onder die nasies af.12 Calvyn gebruik verkies en aanneem wederkerig t.o.v. die bepalende daad van God, met miskien hierdie verskil: "verkies" het meer betrekking op die ewige besluit en ,aanneem" slaan op die historiese daad waardeur God die volk aan Hom verbind. Die verbond realiseer die verkiesing. As wetlike band tussen twee partye, begrens die verbond die kerk op 'n besondere wyse. Daardeur word 'n harmonieuse samelewing in die wêreld sigbaar, wat in eensgesindheid uit gehoorsaamheid aan die wil van God onder leiding van die Heilige Gees groei. ${ }^{13}$

God stel die kerk dan daar soos $\mathrm{Hy}$ dit afgrens wanneer $\mathrm{Hy}$ mense in die wêreld uitwendig deur die verkondiging van die Woord en inwendig deur die verligting van die Heilige Gees roep. ${ }^{14}$ God gee die geloof deur die Heilige Gees, sodat God die mense wat glo, d.w.s. die presiese afmeting van sy kerk ken. Dit is in hulle geloof wat ons die verkiesing van God leer ken. ${ }^{16}$

\section{Net een kerk deur geloof begrens}

Hoe nader ons dus na die sigbare verwerkliking van die verkiesing beweeg, hoe sterker begrens geloof die kerk. Dit is vanweë hierdie belangrike funksie van die geloof dat Calvyn in sy Institusie sy hoofstuk oor die kerk met geloof begin. ${ }^{17}$ Teenoor die Anabaptiste beklemtoon hy dan egter dat niemand op aarde 'n volkome geloof het nie, maar dat die geloof, waarsonder niemand salig word nie, gewerk en versterk moet word deur die prediking van die evangelie. Die sakramente is juis ingestel vir swakke gelowiges om hulle te versterk. Daarmee verwerp hy die opvatting van die Anabaptiste wat die grense van die ware kerk in hulle sigbare gemeenskap as 'n „volmaakte" gemeenskap van gelowiges wou trek. ${ }^{18}$ 


\section{Woordverkondiging gaan aan die kerk vooraf}

Calvyn dink op sterkte van bv. Ef. $2: 20$ aan die herders en leraars wat die profete en apostels opvolg as voor die kerk. Hulle verkondig die Woord wat ons geloof werk en versterk. Die Heilige Gees korrelleer met hulle prediking, en dan kom daar 'n kerk na vore. ${ }^{19}$ „The unifying principle in Calvin's theology is not... the dialectical relation between the Spirit and order, but the absolute correlation to the Spirit and the Word: it is the inseparable of the Spirit and the Son which is the criterion for all theological statements... When the work of the Spirit is correlated with those manifestations of the Word, order - above all the order which describes the church - appears. Thus the church (order) can only be understood dialectically, as refering simultaneously to the Word and to the Spirit". ${ }^{20}$

Dit is belangrik om op Calvyn se denke te let. Vir hom roep God (en nie die sigbare kerk nie) die herders en leraars deur sy Gees (inwendig) met die oog op die onsigbare kerk en daarom gaan die diens aan die sigbare kerkgestalte vooraf. Dit konstitiueer immers die sfeer waarin die onsigbare kerk sigbaar word.

Calvyn se opvatting verskil van Rome en dikwels onder ons gangbare opvattings dat ,die kerk" primêr instituut in en deur sy ampte is en dat die kerk „sy ampte” daarstel. Die kerk is nie vir Calvyn 'n konstitusioneel omlynde instelling wat kragtens voorskrif georganiseer word en daartoe sy organe (ampte) aanwys nie. Goddelike roeping en opdrag stel die diens van die Woord daar voordat daar ' $n$ kerk is of kan wees. Die roeping en diens kan slegs in die gemeente erken en bevestig word.

\section{God alleen ken die wat syne is ${ }^{21}$}

Daar is mense wat kerk is - mense wat die gedaante van kerk vertoon - maar nie kerk is nie. In die gebroke wêreld is daar soms wolwe in die sigbare kerk en kinders buite. Dit verplig ons om met die oordeel van die liefde almal vir die lede van die Kerk van Christus te hou ,wat deur hulle geloofsbelydenis, hulle christelike lewe en hulle deelname aan die sakramente God en Christus saam met ons bely". ${ }^{21}$ Hier neem Calvyn dus die leer (konfessie), die gehoorsame lewe volgens die Woord, die gelowige gebruik van die sakramente en die eenheid in diens as die grense van die sigbare kerk. In hierdie fasette word die een kerk „,voor ons oë openbaar en sienlik".22

\section{Woord en sakrament begrens die kerk}

Calvyn begrens die „kerk” nie soos ons met terme soos „Roomse Kerk, Lutherse Kerk, Hervormde Kerk, Ned. Geref. Kerk of Geref. Kerk" en derglike institusionele begrippe nie. Calvyn dink nie in terme van geïnstitueerde groepe en geobjektiveerde institute nie. Hy sê ,,al die besondere kerke" wat vanweë praktiese noodsaak in stede en dorpe georden is, staan in verband met die algemene kerk, die liggaam van Christus, waaraan hulle die .naain en outoriteit" 
van kerk ontleen. ${ }^{23}$ Dan sê hy: „Want ons moet vir vas en seker hou, sonder om enigsins te twyfel dat in alle plekke, waarin ons opmerk dat God se Woord opreg gepreek en aangehoor word (let op die verbinding preek en hoor. - B.S.) en die sakramente volgens die instelling van Christus bedien word, is ' $n$ kerk en vergadering van God se volk..."

In die volgende paragraaf van die Institusie herhaal Calvyn weer die merktekens van die ware kerk. Daar kom dan 'n klein nuansering na vore. Waar hy in par. 9 praat van bediening van die sakramente volgens die instelling van Christus verskuif die aksent in par. 10 na die gebruik van die sakramente. ${ }^{24}$ Dit onderstreep andermaal dat die kerk vir Calvyn wesenlik mense is. Die kerk is nie wesenlik instituut of struktuur nie, want 'n mens kan nie 'n struktuur of instituut ken en beoordeel aan wat hy preek, hoor of hoe hy nagmaal gebruik nie. Dit is mense wat preek, hoor, sakramente bedien en gebruik. Die Bybel ken volgens Calvyn met die woord „kerk" een van twee: òf die ware kinders van God òf die menigte mense oor die aarde wat bely dat hulle God en Christus ken, al is daar talle hipokrite onder hulle. ${ }^{25}$

\section{Christus-regering begrens die kerk}

Die kerk is immers 'n vorm van die gerealiseerde koninkryk van Christus. Die gelowiges wat kerk is gehoorsaam Hom al op hierdie wêreld en daarom is die kerk vorm van gerealiseerde koninkryk. ${ }^{26}$ Hy sê dat ons inderdaad moet verwag om die kerk te vind waar Christus regeer. ${ }^{27}$

Hy regeer uitwending deur sy Woord en inwendig deur sy Gees met die oog daarop om die imago Dei wat voortskrei na die volmaakte, in die gelowiges na vore te bring. ${ }^{28}$ Die kerk is daar waar mense Christus gewillig en vrywillig volg op die Woord wat uitwendig kom en deur die Heilige Gees wat inwendig werk. ${ }^{29}$ Daarom moet die gemeente oordeel of die predikante die Woord van God suiwer bring soos ambassadeurs van God (Dei legatus). ${ }^{80}$

Die prediking en die leer beteken ten diepste dieselfde. Dit bou. Daarop rus die kerk, die gemeente. ${ }^{31}$ „Wij moeten vasthouden dat de kerk op geen andere wijze gebouwd wordt dan door de uiterlijke prediking, en dat de heiligen door geen andere band onderling verbonden zijn, dan wanneer ze eendrachtig lerend en vordering makend, onderhouden de orde der kerk, die door God is voorgeschreven".32

\section{Die kerk is nie objektiewe struktuur nie}

Calvyn grens die kerk dus nie objektief af as 'n struktuur of groep waarby jy kan gaan aansluit nie - maar die kerk word in die dinamiese lewe, in die relasie waarin elke lid en die gemeenskap tot die lewende Woord staan, geken. In hierdie opsig het ons in die na-Calvynse tyd 'n kerkbegrip ontwikkel wat aan Calvyn vreemd is - nl. dié van die instituut as struktuur.

Toe Calvyn in 1536 diens in Genève aanvaar het, was die ou 
kerkstrukture gesloop. Hy ontwerp nie 'n nuwe struktuur nie. In sy opbouwerk konsentreer hy op die mense sodat hulle een in leer (belydenis) en lewe op die grondslag van die Woord, die ordinatio Dei, sal leef. Daarop word die diens van herders en predikers gerig. Hy verenig Luther se idee van die volkskerk met die Anabaptiste ideaal om die kerk in die suiwer belyders te vind. Gevolglik gee hy aan die kerk in 1536 'n Kategismus en die reeds genoemde Artikels om die diens van die predikante te reël. ,Ze moet een levende gemeenschap zijn, een koninkrijk van Christus op aarde ..." ${ }_{33}$ Hy skryf derhalwe op 21.2.1538 ook aan Bullinger dat slegs die herstel van die apostoliese tugoefening on ekskommunikasie die voortbestaan van die kerk kan verseker.

\section{Die kenmerk van die kerk}

Die kenmerke van die ware kerk trek derhalwe eintlik saam op dic een aspek: „totam inde pendere, si verbum Domini fideliter conservatur, suamque puritatem retineat". Art. 29 van die Nederl. Geloofsbelydenis van 1561 noem die handhawing van die tug 'n derde kenmerk vir die ware kerk. Tog kom die N.Gb. met Calvyn ooreen, wanneer dit die drie kenmerke eintlik tot een reduseer: „Kort gesê, as almal hulle ooreenkomstig die suiwere Woord van God gedra, alles verwerp wat daarteen stry en Jesus Christus erken as die enigste Hoof". Die Woord van God bepaal dus finaliter die grens van die kerk in sy sigbare gedaante. Die profetiese en apostoliese diens in die kerk moet dan ook sorg dat die doctrina, die Woord van God, suiwer bewaar word. Wanneer die kerk (gemeente) nog die tekens van Woord en sakrament het, al is dit vol gebreke, mag niemand van die gemeente afskei nie. ${ }^{31}$

\section{Die kerk is herstelde orde}

Tog moet weer dadelik bygevoeg word dat dit vir Calvyn nie om die formele belydenis as ' $n$ objektiewe suiwer merkteken alleen gaan nie. Die kerk word nie soseer geken aan dokumentêre Belydenisse nie as aan die preek en hoor van die Woord, aan die suiwer bedien en gebruik van die sakramente.

Geloof en gehoorsaamheid (goeie werke) is onmiskenbare vrugte van die prediking. Prediking is die ,moeder" van geloof en omdat die kerk die sfeer is waar die Woord gepreek word, is die kerk moeder van die gelowiges. ${ }^{35}$ Die Heilige Gees moet egter werk in prediker en veral die hoorder. ${ }^{36}$ Dan kom daar 'n nuwe wyse van saamlewe, 'n goeie orde onder die mense na vore, wat die kerk is. Die kerk is dus geskiedenis van die herstel van orde in die wêreld, die sfeer waarin die herskeppende aktiwiteit van die Gees werk. ${ }^{37}$ God trek dus die grens omdat $\mathrm{Hy}$ afskei en herskep, afskei om met Homself te verenig wanneer sy beeld in die mens herskep word. ,The church (order) must always be understood therefore, as existing in the movement from the believer to the Word which occurs in the leading of the Spirit through the ordained means". Die historiese begrip van die kerk, waarby $H$. Küng vandag aan- 
sluit, ${ }^{38}$ sluit die algemeen-gangbare en gearriveerde opvatting onder ons uit van ,an institution in history in which order has already been restored... As a movement of the Spirit the church cannot be regarded as a static, fixed entity, even if it has a certain stability and continuity as a movement of the Spirit through ordained means...".39

\section{Kerk is nie instituut nie maar verus ordo}

Die kerk ,is itself the history of that restoration". ${ }^{\circ 0}$ Wanneer die reformatore pouslike priesters, menslike sonde, afwyking en ver vuiling weerstaan en daarvan padgee, sê Calvyn, skend hulle nie God se verbond nie, beweeg hulle nie van die onaantasbare orde van die kerk af nie. Hulle misken nie die pastoraat en prediking nie, „maar ons ontwyk daardie mense self, sodat die ware orde (verus ordo) herstel mag word ..." Die Rooms-Katolieke beskuldig Calvyn dat hy die kerk verlaat omdat hulle histories en institusioneel die kerk is en Calvyn van die kerk weggebreek het. Calvyn is oortuig dat hy van die pousgesindes geskei het, omdat hulle die kerk verlaat het. Die breuk was nodig sodat die suiwer prediking en waardigheid van die herders herstel kan word. ${ }^{41}$

„He intends a purification of the church which is there before him, a restoration of the true order of the visible church, and not a retreat into some ideal church above and beyond this world".42 So is die kerk in wese organies en dinamies - herstelde orde en nooit objektiewe instituut van herstelde orde nie. Calvyn ken geen „,kerk” as gearriveerde instituut nie.

Die sigbaarheid, konkreetheid, meetbaarheid en kenbaarheid van die universele of ware kerk in die plaaslike of besondere kerkgemeenskap, het dit vir Calvyn selfs moontlik gemaak om te erken dat sekere Roomse gemeenskappe nog inderdaad kerke van Christus kon wees en dat onder die Anabaptiste, ten spyte van hulle dwaling „broeders in Christus" was.43 Teenoor Sadoleto kon hy ontken dat hy 'n nuwe kerk gestig het. „According to Calvin, then, we cannot think of the church as a legally defined institution where the word is truly preached and the sacraments rightly administered, nor can we conceive it mystically, as simply being in the presence of Christ, leaving behind us the objective order. Rather the church must be defined dialectically as union with Christ in, through and together with the means by which the Spirit brings us to Him. We may be led to Christ by the Spirit apart from the means, and we may have the means without the Spirit... but in neither of these cases we have the church". ${ }^{44}$

\section{Die kerk is nie objektiewe (waar of valse) instituut nie}

Die bekende seerplek tussen die NHK van Afrika en die GKSA gaan oor die verklaring van die Sinode 1869 op aandrang van die Chr. Geref. Kerk in Nederland, dat die NHK die „valse kerk” sou wees. Die verklaring moes die afskeiding skematies "wettig" op Hollandse model volgens art. 29 NGb. Die verklaring is met 'n ob- 
jektiewe institusionele kerkbegrip gemaak en ontvang. Calvyn sou seker die verklaring nie soos die GKSA gemaak het nie - en as dit gemaak was, nie die probleme van die NHK van Afrika daaromheen ontwikkel het nie. Ons werk skynbaar by voorkeur met 'n ideële en objektiewe kerkbegrip, asof wat ons „kerk” noem, die onsigbare kerk is (vgl. dieselfde tendens by Rome en die Anabaptiste).

Dit lê seker nie op die weg van hierdie voordrag om Calvyn se opvatting t.o.v. die sogenaamde ,kerk as instituut" (indien hy so 'n opvatting sou gehad het) na te gaan nie. Dit raak egter tog die onderwerp ,grense van die kerk”. Ons bepaal immers die kerk se grense korporatief met ,sy lidmate", lidmaatregisters, attestasies, bewyse van lidmaatskap, geografiese lyne begrens vir ons hierdie kerk teenoor daardie kerk en „ons kerk” teenoor sektes, kerkloses en heidene. Sodoende opereer ons met die idee van 'n idealistiese kollegium, 'n gehipostateerde kerk, 'n korporatiewe instituut. Die hipostatiese noem ons „Kerk" met 'n hoofletter (vgl. bv. die „name” van al drie die Afrikaanse Kerke). Ek meen dat die Ned. Geref. en Ned. Herv. geen beswaar het om die hipostase „Kerk” hulle te laat welgeval nie. Van Geref. kant is daarteen egter beswaar, maar hulle ontloop in later jare al meer hulle probleem deur ,kerkverband" te gebruik in die sin van "kerkgenootskap" of eenheid van gemeentes (,hele kerk"). Calvyn het nooit in 'n dualisme van plaaslike kerk en algemene kerk (kerkverband) gedink nie en nooit die katolieke of universele kerk in sinodale kerke of kerkverbande gaan soek nie. Die universele het vir hom sienlik en konkreet geword in die mense waar en soos hulle deur die Woord en Gees met prediking en sakramente saamgebring is. Dit maak wesenlik verskil of die kerk in mense of in strukture bestaan.

\section{Institusionele is slegs faset van die dinamiese organisme}

Calvyn ignoreer of ontken nie die feit dat die sigbare kerk 'n institusionele faset vertoon nie. Hy praat van die empiriese ,kerk van Korinthe"; 45 die ,pousdom" en ,hulle Kerk" wat vir hom nie dié kerk is nie sodat skeiding met die pousdom nie skeiding van die ware kerk is nie;"4 hy ken die "Roomse Kerk" wie se ,wette" die reformatore nie eerbiedig nie, ${ }^{47}$ ens. Tog laat hy die grens van die een kerk van Christus dwarsdeur die Roomse Kerk loop. Hy onderskei binne die Roomse tussen pousdom en kerk, hierargie of instituut van priesters, wat die Woord van God nie gehoorsaam nie en Roomse gelowiges wat dit wel doen en dus kerk is. ${ }^{18}$

Die kerk is 'n gebou, pilaar en grondslag van die waarheid, wat aaneen gehou word deur die eenheid van geloof (doctrina) en broederlike liefde. ${ }^{49}$ Eenheid in die geloof is voorwaarde vir eenheid in liefde. Elke menslike gemeenskap moet 'n passende bestuur (politia aliqua) hê om onderlinge vrede en eendrag te bewaar. Daarvoor is 'n vaste orde (certis legibus constituta) nodig. Dit is egter hoegenaamd geen geloofsartikels wat vir die saligheid nodig is nie. ${ }^{\circ 0}$ Calvyn beperk die institusionele verordeninge wat ingestel mag word tot net dié wat op die Heilige Skrif berus." ${ }^{51}$ Die Woord van God 
beheers dus ook die institusionele ordening van die kerk. Dus is hierdie formele, konstituerende en ordende bepalinge in diens van die kerk - maar dit konstitueer nie die kerk nie.

Calvyn se kerkbegrip bly basies dinamies. Die kerk bly 'n bewegende lewende organisme, „created, living and historically evolving reality". ${ }^{52}$ Die orde moet pas by die organisme en is aan 'n statiese institusionele patroon of struktuur vreemd. Die orde moet groei, beweeg. Die gelowiges is kerk in hulle daaglikse en gedurige lewe na Christus toe. ${ }^{53}$

\section{Die kerk word sigbaar in liturgie}

Om die prediking te hoor is samekomste nodig. ${ }^{\text {so }}$ Die samekomste is geen hoog-kerklike of geperfeksioneerde groepe nie, maar 'n eenheid in Gees en Waarheid, 'n gemeenskap aan Woord en sakrament onder die werk van die Heilige Gees. Derhalwe word die kerk ook sigbaar in die liturgie. God het ook gebed en lof verorden. Maar ook weer hier moet die liturgie bepaal word deur en uit die Woord van God gebou wees. ${ }^{58}$ Die sakramente is slegs die sigbare Woord (verbum visible) en nodig om die geloof wat die Woord werk te versterk. ${ }^{50}$

$\mathrm{Na}$ sy ervaringe in Genève en Straatsburg met die Anabaptiste handel Calvyn in die 1543 uitgawe van sy Institusie uitvoerig oor die doop. Die doop is die teken en seël van inlywing in die liggaam van Christus, die ware kerk (signum initiationis et insertio in corpore Christi). Die doop onderskei daarom die kinders van die gelowiges van dié van die heidene. Met die doop trek God dus self as 't ware die grens tussen wie binne en wie buite die kerk is (behoudens Calvyn se opvatting oor die ecclesia permixtum). ${ }^{57} \mathrm{Die}$ nagmaal is teken en seël van die voortdurende lewe van die kerk as liggaam van Christus in gemeenskap met die Hoof, Christus.

Met sy korporatiewe pneumatologiese begrip neem Calvyn standpunt in teen die Anabaptiste se atomistiese perfeksionisme. Maar derhalwe is doop en nagmaal as sakramente ook onlosmaaklik verbind. Die grens van die kerk word by uitstek sigbaar in die nag. maalviering terwyl die Anabaptiste dit in die doop gesoek het. Hierin sluit Calvyn aan by Bucer wat die kerk sien as plaaslike kerkgemeenskap wat onder die bediening van hulle herders, leraars, ouderlinge en voorgangers vrywillig saamkom. Die gemeenskap blyk nergens duideliker as rondom die nagmaalstafel en die lyne van die kerk word daar deur die tug getrek.

Calvyn en Farel het reeds in hulle botsing met die Raad van Genève in 1538 op hierdie standpunt gestaan.

\section{Die moeilik begrensbare kerk (ecclesia permixtum)}

Calvyn moes die grense van die kerk na twee kante verdedig, naamlik teenoor Rome en die Anabaptiste. Die Anabaptiste wou die Roomse en reformatoriese kerkinrigting nie erken nie en het gewys op die sondaars in die kerk, die gebreke en geldsug by die kerkdienaars en die alliansie tussen kerk en staat. Daarteenoor het hulle 
hulle kerkgemeenskap, gebou op die atomistiese geloofsbelydenis en doop van hulle aanhangers, geproklameer as die ware kerk van Christus, die vergadering van empiriese „heiliges” en „volmaaktes". Van die kant van die pousdom weer is die reformatore verwyt dat hulle die ware kerk, die struktuur met sy historiese tradisie en inrigting, die mater fidelium waarbuite geen saligheid is nie, verlaat het en ongehoorsaam was aan die gesag van die "kerk".

\section{Die offisiële instituut kan teenoor die kerk te staan kom}

By Rome onderskei Calvyn eintlik tussen pousdom en kerk. As sodanig kan hy toets of binne die Roomse struktuur na die Woord geluister word. So kan Calvyn onderskei tussen die valse kerk in die offisiële pousdom en reste van die ware kerk onder gelowiges wat onder verdrukking van die pousdom verkeer. ${ }^{\text {oo }}$ Wanneer die kerk die ryk is waar Christus regeer, kan Hy nie verwag dat mense in die kerk moet bly waar sonde, dwaling en ongehoorsaamheid aan die Woord aan die orde van die dag is nie. Hoe kan die pousdom eis dat hulle gehoorsaam moet word as hulle self nie aan Christus gehoorsaam is nie? ${ }^{31}$ Hulle is buite die kerk al noem hulle hulle kerk.

Calvyn verwerp ook die Roomse aanspraak dat konsilies die beeld van die kerk vertoon en dat die kerk in die vergadering van herders bestaan." ${ }^{2}$ Die konsilie en herder het alleen gesag indien hulle besluite en bevele ooreenkom met die Woord van God, ${ }^{\text {ss }}$ anders beswaar hierdie kerklike instellings slegs die gewetes van die gelowiges, die ware kerk. Die eenheid van die algemene kerk, die liggaam van Christus, verplig dat daar nooit ligtelik van hierdie kerk afgeskei mag word nie.

Calvyn kan die besware van die Anabaptiste teen die gruwels van kerklike voorgangers en mense in die kerk billik. Gebreke onder die mense van die kerk of verwaarlosing van die tug gee egter geen reg tot breuk nie, omdat die kerk per definisie 'n vergadering van sondaars en swak mense is, soos blyk uit die gelykenisse van die Here Jesus oor die saamwees van goeie en slegtes tot die dag van die oes, die kerk van Korinthe e.a. voorbeelde. ${ }^{.4}$ Selfs in en onder die verrotte Roomse struktuur het God vanweë sy verbond sy kerk wonderlik bewaar. ${ }^{05}$ Ons moet verlang na die suiwerheid in die kerk, maar nooit kan ons in 'n kerk van mense 'n suiwer kerk vind nie.

\section{Die tug as middel om die grense van die kerk te handhaaf}

Calvyn tree die Anabaptiste tegemoet deur die beginsel van heiligheid binne die gegewe onvolmaakte kerk te erken. Die tug is vir Calvyn nie so seer kenmerk van die ware kerk nie as noodsaaklike middel om die kerk te bou en te bewaar. Die tug is basies opvoeding met die Woord van God en begin as 't ware met kategese. Hy wil pastoraal, met groot matigheid en liefde te werk gaan waar hy die Woord van God medies bedien. Die tug is immers vir hom die spiere van die kerk. Sonder tug is die kerk pap en slap en moeilik as kerk kenbaar. ${ }^{08}$ 
Die tug moet egter steeds wees 'n bediening van die sleutelmag, die Woord van God wat salig maak, die geloof werk waardeur God regverdig maak. So handhaaf die tug die eer van God onder diegene wat die naam christen dra, weer die bederf van goeie gelowiges deur slegte mense en kan dit die slegte mens skaam maak, berou werk en hom laat bekeer tot die weg van die lewe. Die tug bly derhalwe afhanklik van die innerlike werk van die Heilige Gees. Die tug is vir Calvyn 'n geestelike regering wat die oordeel van die vergaderinge van herders vereis. Dit verskil wesenlik van die burgerlike regering. Die tug soos Paulus eis, begin met die selfbeproewing wat elke mens ten opsigte van homself en nie ten opsigte van ' $n$ ander nie met die oog op die nagmaal moet beoefen.

Daarna moet die gelowiges in onderlinge toesig volgens die reël in Matt. 18 dit beoefen en eers by hardnekkige volharding, wat neerkom op verwerping van die Woord, wil en wet van God, moet die ekskommunikasie die lyn trek tussen die kerk en die mens wat met ongehoorsaamheid aan die Woord van God in leer of lewe buite die kerk te staan kom." Aan 'n goddelose mens moet 'n mens jou onttrek. Dit is egter radikaal iets anders as om uit haat gemeenskap met die kerk te verbreek.

Tereg merk W. Balke op dat Calvyn die tug noodsaaklik ag met die oog op die sondaar, die stigting van die kerk en die eer van God. Die Doperse ideaal van 'n geobjektiveerde suiwer en ware kerkinstituut is hom vreemd. Die suiwerheid van die kerk moet in die dinamiese en organiese van die kerk as vergadering en gemeenskap van gelowiges na vore kom. Calvyn sê: Ons streef na volmaaktheid soos daar in die liggaam van Christus behoort te wees, maar ons moet ons nie 'n volmaakte kerk inbeeld nie". ${ }^{70}$

„In the conception of disciplinae then, we have the heart of Calvin's doctrine of the Kingdom of Christ... so it drives us to see even more deeply that the last word belongs to justification, that the church conceived as the kingdom of Christ must also be understood as the body of Christ". ${ }^{71}$

Daarom sou 'n mens kon konkludeer dat die tug self die begrensing, omlyning en bewaring van die kerk is. Die doel van die tug is immers berou, versoening en herstel in die gemeenskap wat die kerk is. Dit kan nie bereik word deur uitwendige kerklike handelinge alleen nie maar moet gekorreleer wees met die innerlike werking van die Heilige Gees, sodat God ook daarmee ten diepste die kerk begrens.

\section{Samevatting}

Calvyn se gedagtegang oor die kerk vorm 'n logiese gekonsentreerde eenheid. Hy verstaan die kerk konsekwent dialekties: enersyds as die een ware algemene kerk wat God in sy verkiesende genade en verbond deur die Woord en Gees vergader, beskerm en onderhou en andersyds as 'n organisme, 'n samekoms, 'n vergadering van mense waarin God onvolmaakte mense gebruik en roep tot die volmaaktheid.

Die grens van die kerk word bepaal deur die wil en verorde- 
ning van God en derhalwe uitgewerk deur die prediking van die Woord van God.

Die verband tussen kerk en staat lê in die feit dat beide ontstaan uit die ordening van God. Die grense tussen kerk en staat word eweso bepaal deur dic eie taak, middelle en verantwoordelikheid wat God vir die natuurlike en geestelike orde verordineer het. Die kerk en Woord is nie identies nie. Daarom het die Woord gesag oor dienaars van God in kerk en staat en trek die Woord wat gepreek en aangeneem word die grens tussen kerk en volk, plaaslike gemeenskap en staat.

Die feit dat Calvyn van ordinatio Dei, verkiesing, verbond, roeping, liggaam van Christus tot by die sigbare kerk kom, laat hom die kerk definieer as gemeenskap van lewende swakke mense, wat uit die Woord leef. Hulle moet groei deur die verkondiging van die Woord en die gebruik van die sakramente. Die opvatting van die kerk as organisme, liggaam, volk van God, laat Calvyn nooit van die kerk as 'n hipostatiese instelling, 'n idee, 'n legalistiese korporatiewe entiteit, 'n omlynde statiese struktuur, praat nie. Die begrip „kerk as instituut" is vir Calvyn vreemd en daarom omlyn hy ook nie die kerk met wette, konstitusies of ordes nie - maar gee hy die orde vir die mense wat die bestaande kerk is.

Calvyn praat wel van bv. die Roomse Kerk - maar dan bedoel hy daarmee die sigbare liggaam, waarbinne hy gewoonlik met begrippe soos pousdom, papiste, die pous, die korrupte en valse bestuur onderskei. Wanneer die regeerders en die aanhangers die prediking van die ware Woord nalaat en nie gehoorsaam nie, die sakramente nie bedien en ontvang soos Christus dit ingestel het nie, maar op hulle self vertrou en eie bepalings maak, is dit die valse kerk.

Die term ,,valse kerk" slaan dan nie op objektiewe struktuur nie, maar op die doen en lewe van hulle wat die Woord van God weerstreef. Ook die begrip ,valse kerk" moet daarom nie as 'n statiese strukturele etiket beskou word nie, maar is 'n begrip wat dinamies in die relasie tot en verantwoording aan die Woord aan die lig tree.

Hoe min die Roomse en post-Calvynse institusionalisme met die term ,kerk as instituut" Calvyn se gedagtegang oor die kerk kan weergee, blyk ook uit sy logiese opvatting dat God profete, apostels en herders roep om sy Woord te verkondig sodat die kerk vergader word. Wanneer hierdie dienste aan die kerk voorafgaan kan hulle in wese nie deur instituering of organisasie uit die kerk opkom nie. Calvyn stem daarin met Rome ooreen, diens gaan voor kerk. Maar hy verskil van Rome omdat hy dienste nie met die kerk identifiseer nie. Dus kan ons die kerk nie met die ampte omlyn en defineer as instituut nie.

God het die prediking en die sakramente (dienste) verorden (geïnstitueer) en dit is al wat Calvyn met kerk as instituut sou kon bedoel. Trouens ' $n$ konstitusionele en institusionele begrensing van die kerk moet per definisie die Heilige Gees uitsluit wat by Calvyn sentraal in sy bepaling van die kerk staan. Hoe meer konstitusioneel, formeel, wetties die kerk benader word, hoe minder kan die geestelike karakter en werk van die Gees in ag geneem word. 
Teenoor die oorweldige verstaan van die kerk as instituut in die na-Calvinistiese era van die $19 \mathrm{e}$ en $20 \mathrm{e}$ eeu, teken Calvyn die sigbare kerk met die notae van preek en hoor van die suiwer Woord en bedien en ontvang van sakrament soos Christus dit ingestel het. So is die sigbare kerk nie korporasie (Romeins-regtelik) nie, maar 'n herstelde orde, 'n herskape gemeenskap, nog onvolmaak maar op weg en strydend na die volmaakte. Die kerk is vir Calvyn wesenlik organisme omdat die Skrif die kerk so teken. Hy defineer derhalwe nie deur sy teologie of ekklesiologie nie, maar deur die Woord wat hy as die ordening van God erken.

Die institusionele en konstitusionele wat vir ons dikwels die bepalende organisatoriese grens van die kerk vorm, behoort vir hom volkome tot die non-essensiële en middelmatige dinge. ${ }^{72}$ As iemand in staat was om vir die kerk 'n "konstitusie" te gee, as hy dit wou doen, was dit die regsgeleerde Calvyn. Hy doen dit egter nie, maar omskryf die dienste wat op kerk-wees gerig is.

Die ware kerk is daar waar die koningskap en priesterskap van Christus (regnum et sacerdotium Christi) gevind word. Vir die wese en regering van die kerk moet ons uit hierdie eenheid vertrek. ${ }^{73}$ By hom is geen platoniese dualisme tussen 'n kerkidee en kerkwerklikheid nie. Jy durf nie met die sigbare breek met 'n beroep op die onsigbare nie. Luther se twee ryke en daarom skerp onderskeiding tussen onsigbare en sigbare kerk, is hom vreemd.

Aan die ander kant breek Calvyn ook met die Roomse en Anabaptiste wat die sigbare en onsigbare gedaantes van die kerk met mekaar vereenselwig. Dit is juis Calvyn se pneumatokratiese visie wat hom die kerk met sy unieke mistieke gedaante en aan die ander kant konkrete en empiriese gedaante tot 'n eenheid laat voer. $\mathrm{Hy}$ is verhewe bo die corpus christianum en kerkstaat problematiek van die Middeleeue. Tog kan juis hy deur sy pneumatokratiese opvatting die teokrasie as uitgangspunt neem en tegelyk die katolisiteit van kerk vashou in die veelheid van gebroke beelde om en in die een ware kerk, die liggaam van Christus.

Calvyn se kerkbegrip en ampsleer het hy saam met Bucer in konfrontasie met die Roomse hierargie en doperse separatisme en spiritualisme ontwikkel. Dit is amper ondenkbaar dat hy, geskoolde juris soos hy was, nie ook sou verval het in 'n legalistiese en institusionele kerkbegrip en begrensing nie. Hy behou egter met merkwaardige reglynige gedagtegang die organiese visie op die kerk as 'n lewende organisme. Die kerk bly vir hom ook ten diepste 'n pelgrim en verkeer voortdurend in stryd om sy ware beeld te vertoon en te behou teen al die aanslae, infeksie en verlamming waaraan dit blootgestel is.

Vanuit die ordinatio Dei kom Calvyn derhalwe tot die begrip dat die kerk herstelde orde is wanneer die Wet en Woord van God korreleer met die werk van die Gees in mense. Die Gees gee Christus aan monse ,paralleling the disclosure of election in the general election, of the invisible church in the visible church and the order thereby effected is, of course, faith and obedience". ${ }^{74}$ So leef die kerk deur sy geloof en gehoorsaamheid, sy leer en lewe, meetbaar 
binne in die volle wêreld - 'n profesie van die herstel van orde wat eenmaal ten volle in die wêreld sal kom.

Calvyn se politieke aktiwiteite het dus voortgevloei uit sy verstaan van die kerk. Die kerk is daardie beweging wat die beeld van God in dic mens herstel sodat daardie mens in die wêreld sal werk in die rigting van die nuwe bestemming. Calvyn het die uniekheid van die kerk eerbicdig, maar was tegelyk oop na die wêreld en die toekoms. Hy kon 'n empiries historiese visie met 'n etiese beskouing tot eenheid bring omdat hy die wese van die kerk in mense en die kerk binne die mensdom gesien het. Die kerk egter self is daar waar die Woord van God in prediking en sakramente verkondig en gehoorsaam word - of anders gesê, waar die liggaam van Christus in die plaaslike kerkgemeenskap al is dit selfs onder gebreke, sigbaar word.

Gelewer by die Kongres oor Johannes Calvyn, 11 Augustus 1977 te Pretoria onder beskerming van Die Kerkhistoriese Genootskap van die Ned. Herv. Kerk van Afrika.

1 W. Balke, Calvijn en de Doperse Radikalen, Amsterdam, 1973, p. 42 v, 197.

2 Ibid., p. 59 v. h.a. Institusie 1536. Vgl. J. Calvyn, Institusie ofte Onderwijsingh in de Christelijke Religie, vertaling W. Corsmannus, Brill, 1889, I, $V, 5$.

3 B. C. Milner, Calvin's Doctrine of the Church, Brill, Leiden, 1970, p. 14.

4 Ibid., p. 44.

5 Balke, a.w., p. 64-70.

6 Ibid., p. 47.

7 Ibid., p. 273, 133.

8 Ibid., p. 266 v. Calvyn in 1536: ut inter Chrisianos publica religionis facies existat, inter hoines constet humanitas.

9 Ibid., p. 267.

10 Ibid., p. 70-71.

11 J. Calvyn, Institusie, IV, i, 2.

12 Ibid., III, xxii, 7, 8, 10. Vgl. J. Calvyn, Commentaries, Edinburgh, 1850 op Gen. $17: 7$, Joh. $6: 37-40$, Joh. $17: 9$, Joh. 10 ens. D. C. S. van der Merwe, Verbond en Sending (PU vir CHO, 1965, p. 98 v. h.a. W. van den Bergh, Calvyn over het genadeverbond, 's Gravenhage, 1879.

13 Milner, a.w., p. 49.

14 J. Calvyn, Commentaries, Joh. 6 : 40. Institusie III, xxiv, 2, 4.

16 Milner, a.w., p. 61, h.a. U. Calvyn, Tract Predestination, p. 113. Vgl. ook Commentaries Jes. $31: 6,43: 19$, Jer. $7: 21-24$. Institusie, IV, ii, 2.

17 J. Calvyn, Institusie, IV, i, 1.

18 Balke, a.w., p. 56.

19 J. Calvyn, Institusie, IV, i, 1; IV, iii, 1, 7.

20 Milner, a.w., p. 4.

21 J. Calvyn, Institusie, IV, i, 8.

22 Ibid. en par. 9.

23 Ibid., IV, i, 9. Ek kursiveer.

24 Ibid., IV, i, 10. 
25 Ibid., IV, i, 7.

26 J. Calvyn, Commentaries Ps. $145: 10$, Joh. $10: 16$ ens.

27 Ibid., 1 Thess. $1: 1$.

28 Milner, a.w., p. 171. J. Calvyn, Commentaries Luk, $17: 20,19$ : 12, Ef. $2: 20$.

29 Ibid., Miga $4: 3$, Ps. $75: 2$.

30 Ibid., 1 Kor. $14: 29,2$ Kor. $5: 18$.

31 Ibid., Ef. $2: 20,1$ Tim. $5: 17$.

32 Balke, a.w., p. 1, 215.

33 Ibid., p. 76.

34 Ibid., p. 116 v, Institusie 1539 met beroep op Fil. $3: 15$.

35 J. Calvyn, Institusie IV, i, 9, 10.

36 J. Calvyn, Commentaries Rom. $11: 14$, Joh. $15: 3$.

37 Ibid., Eseg. 20 : 12.

38 H. Küng, The Church, London, 1973, p. 6, 13, 4, 85 ens.

39 Milner, a.w., p. 194.

40 Ibid., p. 47.

41 J. Calvyn, Commentaries Mal. $2: 4$.

42 Milner, a.w., p. 155.

43 Ibid., p. 156. I.v.m. Calvyn se eenheid met Boheemse broeders. Vgl. Balke, a.w., p. 150 v.

44 Milner, p. 133.

45 J. Calvyn, Institusie, IV, i, 14.

46 Ibid., IV, ii, 2.

47 Ibid., IV, ii, 3, 5.

48 Ibid., IV, ii, 4. Vgl. Commentaries Joh. 10, $7: 40$ ens.

49 Ibid., IV, ii, 5. Vgl. ook IV, ii, 1 en sy verwysing na Ef. $2: 20,1$ Tim. 3 : 15

50 Ibid., IV, x, 27. J. Calvyn, Commentaries 1 Kor. $14: 49,11: 2$.

51 Institusie, IV, $\mathbf{x}, 30$.

52 Milner, a.w., p. 7, verwys na Wendel, Calvin (1963), p. 295 v.

53 J. Calvyn, Commentaries Eseg. $11: 5$.

55 Vgl. J. Calvyn, Institusie IV, 1, 5. Commentaries Jes. 59: 21, Rom. $10: 17$ ens.

56 Milner, a.w., p. 157 verwys na Commentaries Ps. 52 : 8, Hos. 9 : 5, Matt. 22 : 21 ens.

57 J. Calvyn, Institusie IV, xvi, 4, 13, 24. Commentaries Gen. 17 : 7. Milner, a.w., p. 123 verwys na Tract, Appendix to the Tract on the true method of reforming the church.

58 Balke, a.w., p. 93.

59 J. Calvyn, Commentaries Gen. $17: 7$, Jes. $20: 2$.

$60 \mathrm{~J}$, Calvyn, Institusie, IV, ii, 12.

61 Ibid., IV, ii, 2, 4, 9; IV, x, 18.

62 Ibid., IV, ix, 1, 7.

63 Ibid., IV, ix, 8; IV, x, 6.

64 Ibid., IV, i, 12, 12, 14, 15.

65 J. Calvyn, Commentaries Eseg. $16: 2$.

66 Balke, a.w., p. 49.

67 J. Calvyn, Institusie IV, i, 7.

$68 \mathrm{Vgl}$. by Balke, p. $50 \mathrm{v}$, reeds in uitgawe van Institusie 1536. J. Calvyn, Institusie IV, i, 15, 22; IV, iii, 4; IV, x, 28, 29; IV, xi, 1, 3, 4, 5; IV, xii, 
1, 579.

69 Vgl. ibid. IV, hfst. xii.

70 Vgl. Balke as p. 225 v. en aanhaling $\mathrm{CO} 7,66$. Tug behoort tot die substansie van die kerk, tog bepaal dit nie die wese van die kerk nie, $p$. 227 h.a. CO 7, 68. Vgl. ook Milner, a.w., p. 175.

71 Milner, a.w., p. 178 v.

72 J. Calvyn, Institusie IV, ë, 30, 31, 32.

73 J. Calvyn, Commentaries Jer. $33: 17-18 ; 1$ Kor. $1: 30$.

74 Milner, a.w., p. 81. 